\title{
Establishment Of Village Regulations In Realize Autonomy Village
}

\author{
Roy Marthen Moonti \\ Faculty of Law, Universitas Gorontalo \\ email: roymoonti16@gmail.com
}

\begin{abstract}
Provision of regional autonomy is the granting of authority and flexibility to regions to manage and utilize regional resources optimally, of course, the granting of such authority must be balanced with the establishment of adequate regulations. However, there are still many problems related to the formulation of regulations, especially the village regulations. As long as government-cooled development starts from the lowest levels of government, the village has not proceeded as desired. The purpose of this study to determine the Status of Village Rules In Autonomy Village Governance System. The research method used in the preparation of this research is the normative juridical method that is in answering the problem used the legal point of view based on the applicable law regulation, to then be connected with the reality in the field related to the issues to be discussed. Village regulations serve as indicators in the successful implementation of village autonomy. In Law Number 6 Year 2014 Article 115 letter b and e jo Article 112 paragraph 1 stipulates the provision that the Regency / Municipal Government shall supervise and administer the Village Government which in the case of Village Regulation in the form of guiding the formulation of Village Regulation and Village Head Regulation as well as evaluating and supervision of Village Rules.
\end{abstract}

Keyword: village; village regulation; autonomy

\section{INTRODUCTION}

Of the 1945 Constitution of the Republic of Indonesia article 1 paragraph (3) which states that the State of Indonesia is a state law. ${ }^{1}$ It aims to create legal order and legal certainty for the life of government organizations in Indonesia, which is based on law. The Unitary State of the Republic of Indonesia based on the law (rechtsstaat) is not based on the mere power (machtsstaat) which is clearly defined in the body of the Constitution of the Republic of Indonesia Year $1945 .{ }^{2}$

Provision of regional autonomy as widely as possible means giving authority and flexibility to the region to make the regional resources can be utilized optimally, although the emphasis of autonomy is placed at the level of Regency / City, but the essence of

${ }^{1}$ Undang Undang Dasar Negara Republik Indonesia Tahun 1945 Pasal 1 Ayat 3

2Dasril Rajab, Hukum Tata Negara Indonesia, Rineka Cipta, Jakarta, 2005, hal. 74 
independence should start from the level of government at the lowest level, The village as a support area at a higher level. ${ }^{3}$

The course of the state history of this republic, the arrangement of the Village has undergone several changes since the Colonial Age, Regeeringsreglement, which was the beginning of the village administration. At least there are some rules of legislation that emerged since 1945, among others, Law no. 1 of 1945 on the Status of the Village and the Power of the National Committee of the Region, the Decree of the MPRS No. III / MPRS / 1960 on the Outline of the Planet Development Pattern of First Stage 1961-1969, Law no. 5 The year 1979 on Village Government, PP. 76 of 2001 on General Guidelines on Village Regulation, PP. 72/2005 on Villages, Government Regulation No. 47 of 2015, Law No. 6 of 2014 on Villages, hereinafter referred to as the Village Law.

Refer a statement about Village Autonomy that: ${ }^{4}$ The village is a unitary legal community that has its original structure based on special privileges of origin. The basic concept of thinking about village governance is diversity, participation, indigenous autonomy, democratization and community empowerment.

Observing village geography is a result of geographical, social, political, and cultural manifestations in one region and having a reciprocal relationship with other regions, ${ }^{5}$ the definition is, in fact, the village is an important part for the existence of the Indonesian nation because the village is the smallest unit of this nation that shows the diversity of Indonesia. As long as it is proved that diversity has become a support force for the existence of a nation. Thus the strengthening of the village becomes a thing that cannot be negotiable and can not be separated from the development of this nation as a whole. Thus, the existence of the village needs to be empowered and protected, especially in the exercise of its authority.

Historically, the village was the forerunner to the formation of political and governmental society in Indonesia long before the nation was formed. The social structures that exist in similar areas of villages, indigenous peoples, and others have become social institutions that have a very important position. The village is an autonomous institution with its own traditions, customs, and laws and has an independent tendency. This is demonstrated, among other things, by the high level of diversity that the village may be the most concrete form of the nation. However, in Law Number 23 the Year 2014, it is mentioned that villages in districts/municipalities can gradually be changed or adjusted their status to urban village according to the proposals and initiatives of the Village Government

${ }^{3}$ Thomas, Pengelolaan Alokasi Dana Desa dalam Upaya Meningkatkan Pembangunan di Desa Sebawang Kecamatan Sesayap Kabupaten Tana Tidung. Jurnal Pemerintahan Integratif, Volume 1 Nomor 1, 2013, hal.5164

${ }^{4}$ HAW Widjaja, 2003. Pemerintahan Desa/Marga. PT. Raja Grafindo Persada. Jakarta. HIm. 3.

${ }^{5}$ R. Bintaro, Dalam Interaksi Desa - Kota dan Permasalahannya (Jakarta: Ghalia Indonesia, 1989). 
together with the Village Consultative Board established with the regional regulation. Assuming that people in the region are more characteristic of urban communities. ${ }^{6}$

In connection with the enactment of Law Number 12 the Year 2011 on the Establishment of Laws and Regulations, Village Regulations are not explicitly regulated. Previously in Law no. 10 of 2004 and the Minister of Home Affairs Regulation No. 17 of 2006 on the Gazette and Regional News stipulates that Village Regulation is enacted in the Regional News. Although Law Number 12 the Year 2011 does not stipulate explicitly about village regulations, it does not mean that Law Number 12 the Year 2011 does not recognize village regulations as legislation. Village regulations are still recognized as legislation under the provisions of Article 8 of Law Number 12 the Year 2011 which reads: ${ }^{7}$

1. Types of Legislation Regulations other than those referred to in Article 7 paragraph (1) include the rules established by the People's Consultative Assembly, the People's Legislative Assembly, the Regional Representative Council, the Supreme Court, the Constitutional Court, the Supreme Audit Board, the Judicial Commission, Bank Indonesia, A Minister, a body, body or commission of the same level established by law or Government on the order of the Act, Provincial People's Legislative Assembly, Governor, Regency / Municipal House of Representatives, Regent / Mayor, Village Head or equivalent.

2. The legislation, as referred to in paragraph (1), is acknowledged to exist and has binding legal force as long as it is ordered by a higher Legal Regulation or is established on the basis of authority.

Based on the above background the author takes a problem formulation in this research is how the position of village rules in the autonomous village government system.

\section{METHOD}

The research method used in the preparation of this research is the normative juridical method that is in answering the problem used the legal point of view based on applicable law ${ }^{8}$ to be further connected with the reality in the field related to the issues to be discussed. ${ }^{9}$

\section{ANALYSIS AND DISCUSSION}

\section{Position of Village Rules in Autonomy Village Governance System}

The village government is a formal symbol of the village community. The village government as the lowest authority institution, in addition to having the original authority to

\footnotetext{
${ }^{6} \mathrm{HAW}$ Widjaja. Otonomi Desa Merupakan Otonomi yang Asli Bulat dan Utuh, Raja Grafindo,Jakarta, 2004, hal.4

${ }^{7}$ Pasal 8 Undang Undang Nomor 12 Tahun 2011 Tentang Pembentukan Peraturan Perundang Undangan.

${ }^{8}$ Nurul Qamar, et.al. Metode Penelitian Hukum, Social Politic Genius (SIGn), 2017. hal, 50

${ }^{9}$ Bambang Sunggono, Metodologi Penelitian Hukum, Raja Grafindo Persada, Jakarta, 2002, hal.43
} 
regulate its own household (autonomous authority) also has the authority and power as a gradual delegation from the government above it. The village government is organized under the leadership of a village head and his or her assistant village head in organizing or running village governance. ${ }^{10}$

If we trace the history of village setting we can start in 1854, the Dutch colonial government issued regeeringsreglement which was the forerunner of the arrangement of the region and the village. In article 71 or article 128.I.S. affirming the status of the village, firstly that the village which is the regulation is called inlandsche gemeenten for the approval of the regional head is entitled to elect his own village leader and government. Secondly, that the village head was given the right to organize and manage his own household by taking into account the regulations issued by the governor-general or from the regional head (resident), the Governor-General shall safeguard that right against all violations. ${ }^{11}$

The regulation has also succeeded in promoting the advancement of village legal status as the owner of its natural resources, in terms of legal history studies, it can also be observed that the regulation of the village as mentioned above has the potential to generate debate among academics as well as internal colonial government. According to Van Deventer, with the passage of village rules, the right of villages to obtain and control their own property has been given a legal basis. Based on the right, the village will be able to arrange their own village income. This is important in relation to the establishment of village schools and village barns at that time. ${ }^{12}$

The existence of Village Rules as one form of legislation since the enactment of Law Number 22 the Year 1999 on Regional Government, and from the moment stated as applicable then as one of the tasks of the Village Representative Body is a body formed as the realization of democracy at the village level. The enactment of Law Number 32 the Year 2004 regarding Regional Government, still recognizes and reinforces Village Regulation although it still has not provided a definition or definition of what is meant by Village Regulation. The definition of the Village Rule is mentioned in Article 1 of Law Number 10 the Year 2004 on the Establishment of Legislation, namely the Legislation Regulation made by the village representative body or other names together with the village head or other names. This definition is also used by Government Regulation No. 72 of 2005 which is a further regulation of the Village. Further things about the village regulations themselves have not been regulated in Law Number 32 the Year 2004 or Government Regulation

${ }^{10}$ Dody Eko Wijayanto, Kepala Desa Dengan Badan Permusyawaratan Desa Dalam Pembentukan Peraturan Desa. Jurnal Independent.

11 Rahardjo, Pengantar Sosiologi Pedesaan dan Pertanian,Gadjah Mada University Press, Yogyakarta, 1999, hal.12

12 Ibid, hal. 14 
Number 72 the Year 2005 firmly stated. However, both regulations have mandated that further matters concerning Village Rules are regulated in each region by referring to the Minister of Home Affairs Regulation No. 29 of 2006 Challenging Guidelines for Establishment and Mechanism of Village Rule Preparation. ${ }^{13}$

The recognition of the existence of Village Rules and having binding legal force as long as ordered by a higher regulation or established under the authority (formal), reinforced in Article 8 paragraph (2) of Law Number 12 the Year 2011. Based on Article 101 of Law Number 12 In Year 2011, all laws and regulations that are the implementing regulations of Law Number 10 the Year 2004 are declared valid as long as they are not contradictory to the provisions of Law Number 12 the Year 2011. Thus, although Law Number 10 the Year 2004 has been revoked the Government Regulation is still in effect, also the Government Regulation of Law Number 32 the Year 2004 which as the implementer of the article on the Village in the Act, namely Government Unity Number 72 the Year 2005 regarding Village. Although the Village Government cannot simply form a Village Rule to elaborate a higher-level Legislation if there is no order from the Regulation or delegation because the original affairs or authorities held by the village are very limited.

The position of the Village Regulation actually still includes the legislation. This is based on the provisions of Article 8 of Law Number 12 the Year 2011 on the Establishment of Laws and Regulations: ${ }^{14}$

1. The types of legislation other than those referred to in Article 7 paragraph (1) include the regulations stipulated by the People's Consultative Assembly, the People's Legislative Assembly, the Regional Representative Council, the Supreme Court, the Constitutional Court, the Supreme Audit Board, the Judicial Commission, Bank Indonesia, a commission, body or commission of the same level established by law or Government on the order of the Act, Provincial People's Legislative Assembly, Governor, Regency / Municipal House of Representatives, Regent / Mayor, Village Head or equivalent.

2. The laws and regulations referred to in paragraph (1) are recognized and have the binding legal force to the extent required to be ordered by a higher Legal Regulation or established by authority.

The concept of a democratic constitutional state of the existence of legislation, including the Village Regulations in its formation, must be based on several principles, which can be distinguished in two (2) categories of legislation formation of appropriate

${ }^{13}$ Saiful, 2014, Eksistensi Peraturan Desa Pasca Berlakunya Undang Undang Nomor 12 Tahun 2011. Jurnal Ilmu Hukum Legal Opinion

${ }^{14}$ Pasal 8 Undang Undang Nomor 12 Tahun 2011 
legislation (beginselen van behoorlijk regelgeving), ie formal principles and material principles. ${ }^{15}$

Formal principles include:

1. The principle of clear objectives (Het beginsel van duideijke doelstellin);

2. The principle of the right institutions (Het beginsel van het juiste orgaan);

3. The principle of necessity of setting (Het noodzakelijkheid beginsel);

4. The principle can be implemented (Het beginsel van uitvoorbaarheid);

5. The principle of consensus (het beginsel van de consensus).

Material principles include :

1. The principle of clarity of terminology and systematics (het beginsel van de duiddelijke terminologie en duidelijke systematiek);

2. The principle that legislation is easy to recognize (Het beginsel van den kenbaarheid);

3. The principle of equality (Het rechts gelijkheids beginse);

4. The principle of legal certainty (Het rechtszekerheids begin sel);

5. The principle of the implementation of the law according to individual circumstances (Het beginsel van de individuelerechtsbedeling). ${ }^{16}$

Article 5 of Law Number 12 Year 2011 Juncto Article 137 of Law Number 23 Year 2014 stipulates that the Regional Regulation in which includes the Village Regulation is formed based on the principle of the establishment of legislation, and in the formulation of laws and regulations that are regulatory, including regulations regions must also comply with the principle of content as regulated in Article 6 of Law Number 23 the Year 2014 juncto Article 138 of Law Number 23 the Year 2014.

Referring to the principles described above that there is another side that must be understood by those who have the power or authority in establishing the Village Rule, that is, those with the authority should understand all sorts of issues in depth and the background of the issues and contents that will be governed by Village Rules. This will be closely linked to the implementation of the above principles.

Village Regulation is a legal instrument for the implementation of the Village Government in exercising the authority of the Village. So that the Village Rule in accordance with Law Number 6 the Year 2014 serves to organize the Village Government in the case of village authority to regulate the exercise of the power granted based on the right of the origin and local authority within the Village area. The arrangement model can be interpreted that Village Rule has functioned as an instrument of the implementation of

${ }^{15}$ Abdul Latif dan Hasbi Ali, Politik Hukum, Sinar Grafika, Jakarta, 2010, hal.62

${ }^{16} \mathrm{lbid}$ 
village autonomy as previously explained that the position of the Village is located in the Regency / City area. In addition, it is necessary to observe the regulation of Article 115 letter b and e jo. Article 112 Paragraph (1) of Law Number 6 the Year 2014 which stipulates that the Regency / Municipal Government shall supervise and administer the Village Administration, in the case of Village Regulation in the form of providing guidance on the preparation of Village Regulation and Village Head Regulation as well as evaluating and supervising Village Regulation. This provision makes clear that the function of the Village Rule remains unchanged, ie functioning in the context of good governance.

It also needs to be seen that through the regulation of Law No. 6 of 2014 related to the Village Regulation it is clear that the reins of power and the administration of village government are in the Village Head. Head Describe bodies that in addition to implementing legislation, is also a body that establishes the Village Rules in order to maintain national stability. ${ }^{17}$ This confirms the position and function of BPD that has been discussed in the previous chapter. It is clear that the democratization in the village is generally carried out through the Village Head, with the BPD as the village parliament and the democratization of the village into an institution that participates through its supervisory function..$^{18}$ This democratization is carried out within the framework of village autonomy which is actually more blurred, where the Village Government in accordance with Law No. 6 of 2014 cannot be fully autonomous but remains in the unitary state system of the Republic of Indonesia.

\section{CONCLUSION}

Village Regulation is one of the implementations of village regulations in implementing all forms of authority in the village. By him the village regulations in this case Law No. 6 of 2014 which aims to organize the Village Government to and regulate the implementation of local-scale authority in the Village. This can be interpreted that the Village Rule serves as an indicator in the successful implementation of village autonomy. In Law Number 6 Year 2014 Article 115 letter b and e jo Article 112 paragraph (1) stipulates the provision that the Regency / Municipal Government shall supervise and administer the Village Government which in the case of the Village Regulation in the form of guiding the formulation of Village Regulation and Village Head Regulation evaluation and supervision of Village Rules.

\footnotetext{
17 Qamar, Nurul; Mustamin, Hikmawati; Aswari, Aan. Local Wisdom Culture of Bugis-Makassar in Legal Perspective. ADRI International Journal Of Law and Social Science, 2017, 1.1:35-41.

${ }_{18}$ Baharuddin, Hamza. Functions of the House of Representatives of the Regional (DPRD) Life in Making Democracy in the Region. JL Pol'y \& Globalization, 2013, 14: 43.
} 


\section{REFERENCE}

Abdul Latif dan Hasbi Ali, (2010), Politik Hukum, Sinar Grafika, Jakarta.

Baharuddin, Hamza. (2013). Functions of the House of Representatives of the Regional (DPRD) Life in Making Democracy in the Region. JL Pol'y \& Globalization, 14: 43.

Bambang Sunggono, (2002), Metodologi Penelitian Hukum, Raja Grafindo Persada, Jakarta.

Dasril Rajab, (2005), Hukum Tata Negara Indonesia, Rineka Cipta, Jakarta.

Dody Eko Wijayanto, Kepala Desa Dengan Badan Permusyawaratan Desa Dalam Pembentukan Peraturan Desa. Jurnal Independent.

HAW Widjaja, (2003). Pemerintahan Desa/Marga. PT. Raja Grafindo Persada. Jakarta.

HAW Widjaja. (2004). Otonomi Desa Merupakan Otonomi yang Asli Bulat dan Utuh, Raja Grafindo,Jakarta.

Matutu, Mustamin Daeng; Latief, Abdul; Mustamin, Hikmawati. (2004). Mandat, Delegasi, Attribusi Dan Implementasinya Di Indonesia. UII Press, Yogyakarta.

Qamar, Nurul; et.al. (2017). Metode Penelitian Hukum, Social Politic Genius (SIGn), Makassar.

Qamar, Nurul; Mustamin, Hikmawati; Aswari, Aan. (2017). Local Wisdom Culture of BugisMakassar in Legal Perspective. ADRI International Journal Of Law and Social Science, 1.1: 35-41.

R. Bintaro, (1989), Dalam Interaksi Desa - Kota dan Permasalahannya (Jakarta: Ghalia Indonesia.

Rahardjo, (1999). Pengantar Sosiologi Pedesaan dan Pertanian,Gadjah Mada University Press, Yogyakarta.

Saiful, (2014), Eksistensi Peraturan Desa Pasca Berlakunya Undang Undang Nomor 12 Tahun 2011. Jurnal Ilmu Hukum Legal Opinion. 
Thomas, (2013), Pengelolaan Alokasi Dana Desa dalam Upaya Meningkatkan Pembangunan di Desa Sebawang Kecamatan Sesayap Kabupaten Tana Tidung. Jurnal Pemerintahan Integratif, Volume 1 Nomor 1.

Undang-Undang Dasar Negara Republik Indonesia Tahun 1945

Ketetapan MPRS No. III/MPRS/1960 tentang Garis-Garis Besar Pola Pembangunan Semesta Berencana Tahapan Pertama 1961-1969,

Undang-Undang No. 1 Tahun 1945 tentang Kedudukan Desa dan Kekuasaan Komite Nasional Daerah.

Undang-Undang No. 5 Tahun 1979 tentang Pemerintahan Desa

Undang-Undang Nomor 6 Tahun 2014 tentang Desa

Undang Undang Nomor 23 Tahun 2014 tentang Pemerintahan Daerah

Undang Undang Nomor 12 Tahun 2011 tentang Pembentukan Peraturan Perundangundangan

Peraturan Pemerintah Nomor. 76 Tahun 2001 tentang Pedoman Umum Pengaturan mengenai Desa

Peraturan Pemerintah Nomor 47 Tahun 2015 tentang Perubahan Atas Peraturan Pemerintah Nomor 43 Tahun 2014 Tentang Peraturan Pelaksanaan Undang Undang Nomor 6 Tahun 2014 Tentang Desa

Peraturan Pemerintah Nomor 72 Tahun 2005 tentang Desa

Peraturan Menteri Dalam Negeri Nomor 17 Tahun 2006 tentang Lembaran dan Berita Daerah mengatur bahwa Peraturan Desa diundangkan dalam Berita Daerah

Peraturan Menteri Dalam Negeri Nomor 29 Tahun 2006 Tantang Pedoman Pembentukan Dan Mekanisme Penyusunan Peraturan Desa 